\title{
Uniform Amplification of a Mixture of Deoxyribonucleic Acids with Varying GC Content
}

\author{
Namadev Baskaran, Rajendra P. Kandpal, ${ }^{1}$ Ajay K. Bhargava, ${ }^{2}$ \\ Michael W. Glynn, ${ }^{3}$ Allen Bale, ${ }^{3}$ and Sherman M. Weissman ${ }^{4}$
}

Boyer Center for Molecular Medicine, ${ }^{3}$ DNA Diagnostic Laboratory, Department of Genetics, Yale

University School of Medicine, New Haven, Connecticut 06536

A PCR method for uniform amplification of a mixture of DNA templates differing in GC content is described using the two enzyme approach (Klentaql and Pfu DNA polymerase) and a combination of DMSO and betaine. This method was applied to amplify the CGG repeat region from the fragile $X$ region.

Development of PCR for the amplification of nucleic acids has revolutionalized several fields of molecular biology. Since the introduction of this method several parameters of the system have been modified to amplify longer nucleic acid fragments (Foord and Rose 1994, and references within). A variety of DNA polymerases have been used for PCR because of their improved thermal stability (Lawyer et al. 1993) and editing functions (Lundberg et al. 1991; Mattila et al. 1991). Use of a two-enzyme approach (Klentaq1 and Pfu DNA polymerase) has enabled the amplification of fragments up to $35 \mathrm{~kb}$ in length (Barnes 1994; Cheng et al. 1994).

Several reagents have been shown to facilitate DNA strand separation either because they disrupt base pairing [e.g., dimethylsulfoxide (DMSO), formamide] or isostabilize DNA [e.g., tetraalkylammonium (TAA) salts such as tetramethylammonium chloride (TMAC), tetraethylammonium chloride, and $\mathrm{N}, \mathrm{N}, \mathrm{N}$-trimethylglycine (betaine)] (Melchior and von Hippel 1973; Rees et al. 1993). Some of these reagents have been included in PCR reactions to amplify GCrich templates. Recently, it has been shown that at lower concentrations TMAC can enhance the amplification of AT-rich DNA fragments, and at

Present addresses: 'Fels Institute for Cancer Research and Molecular Biology, Temple University School of Medicine, Philadelphia, Pennsylvania 19140; ${ }^{2}$ Institute for Bones and Joint Disorders and Cancer, Bayer Corporation, Pharmaceutical Division, West Haven, Connecticut 06516.

${ }^{4}$ Corresponding author.

E-MAIL weissman@biomed.med.yale.edu; FAX (203) 737 2286. higher concentrations it can inhibit enzyme amplification (Chevet et al. 1995). However, templates with high GC contents are variably amplifiable or completely unamplifiable even with the addition of DMSO, formamide, glycerol, TMAC, or 7-deazaguanosine triphosphate (7cdGTP), which lowers the melting temperature of the substituted DNA (McConlogue et al. 1988; Bookstein et al. 1990; Hung et al. 1990; Sarkar et al. 1990; Pomp and Medrano 1991). In spite of all the advances described above there is no single method that has been developed that could amplify to a similar extent all DNA templates in a heterogeneous mixture.

There are a number of PCR applications (e.g., construction of cDNA library from a small number of cells, representational differential analysis of two different genomic DNA, or cDNAs from two different cell types) for which it would be highly desirable to have a method whereby a mixture of DNA fragments of similar length (0.5$10 \mathrm{~kb}$ ) can be amplified with equal efficiency regardless of base composition. Therefore, we explored amplification by using isostabilizing quarternary amines that did not inhibit the DNA polymerases. Betaine is a natural amino acid ana$\log$ and has many useful properties such as osmoprotection of Escherichia coli cells, stabilization of proteins against thermal denaturation, and isostabilization of DNA (Csonka 1989; Santoro et al. 1992; Rees et al. 1993). However, use of betaine as a reagent for amplification of $\mathrm{GC}$-rich templates has not been explored.

In this report we studied the efficiency of amplification of individual templates when ampli 


\section{BASKARAN EI AL.}

fied in the presence of a mixture of four templates of differing GC content using a modified protocol that included betaine and DMSO. This protocol was also applied to amplify normal and premutation alleles of the highly GC-rich CGG repeat of the fragile $X$ region.

\section{RESULTS AND DISCUSSION}

\section{PCR Using AmpliTaq DNA Polymerase}

Attempts to amplify the two GC-rich templates, MHCcln1, from the major histocompatibility (MHC) region (64\% GC), and OCT-T1, from the octamer-binding protein (OCT) (80\% GC), by AmpliTaq DNA polymerase under standard conditions (Saiki et al. 1988) with or without denaturants such as DMSO (10\%-15\% vol/vol), betaine (up to $2.5 \mathrm{M})$, glycerol $(10 \% \mathrm{vol} / \mathrm{vol})$, formamide $(2.5 \%-10 \% \mathrm{vol} / \mathrm{vol})$, and TMAC $(0.1$ $\mathrm{mm}-1 \mathrm{M}$ ), were unsuccessful (data is not shown). The other two non-GC-rich templates, (OCT1 (52\% GC) and transferrin receptor (TFR) (44\% GC), were amplified by AmpliTaq DNA polymerase without the addition of denaturants. Several TAA salts at high concentrations $(>1 \mathrm{M})$ have been shown to have an isostabilizing effect on DNA (Melchior and Von Hippel 1973; Rees et al. 1993). However, TMAC at such high concentrations inhibited enzyme function (Chevet et al. 1995). We also observed inhibition of the amplification of OCT1 in the presence of TMAC $(>100$ $\mathrm{mm}$ ). We chose betaine, a zwitterionic form of TAA, because of its protection of proteins against thermal denaturation and its isostabilization effect on DNA (Santoro et al. 1992; Rees et al. 1993) and studied its effects on amplification of GCrich templates. Addition of betaine $(>1 \mathrm{M})$ did not promote the amplification of the GC-rich OCT$\mathrm{T} 1$ and inhibited the amplification of the nonGC rich template OCT1.

\section{PCR Using the LA System}

We tested the amplification of each of these fragments with the LA system (Barnes 1994), which combines a highly thermostable form of Taq DNA polymerase (Klentaq1, which is devoid of 5 '-exonuclease activity) and a proofreading enzyme ( $P f u$ DNA polymerase, which has $3^{\prime}$ exonuclease activity). PCR reactions were performed with and without the addition of betaine, DMSO, formamide, glycerol, tetramethylammonium acetate (TMAA), and TMAC. All four tem- plates, TFR (44\% GC), OCT1 (52\% GC), MHCcln1 (64\% GC), and OCT-T1 ( $80 \%$ GC), were amplified to a similar extent in the presence of betaine $(2.2 \mathrm{~m})$ or DMSO $(10 \% \mathrm{vol} / \mathrm{vol})$ (Fig. $1 \mathrm{~A}$, lanes 1-12). Amplification of the two GC rich templates was not possible in the absence of DMSO or betaine (Fig. 1A, lanes 7,10). Addition of 5\% DMSO or $1.1 \mathrm{~m}$ betaine enabled amplification of MHCcln1, whereas amplification of OCT-T1 required $10 \%$ DMSO or $>1.5 \mathrm{~m}$ betaine in the PCR reaction (data not shown) probably because the required amount of denaturants varies with the GC content of the templates. Amplification of OCT1 was abolished in the presence of higher concentrations of TMAC ( $>100 \mathrm{~mm})$, TMAA $(>100 \mathrm{~mm})$, formamide ( $>5 \% \mathrm{vol} / \mathrm{vol})$, and DMSO $(>15 \% \mathrm{vol} / \mathrm{vol})$. Although betaine at high concentrations $(>1.0 \mathrm{M})$ inhibited AmpliTaq DNA polymerase, it did not affect the LA system, probably because of the higher stability of Klentaq 1 (Barnes 1992). All four templates (TFR, OCT1, MHCcln1, and OCT-T1) were also tested using two of the commercially available two-enzyme systems (the expand long template PCR system from Boehringer Mannheim and XL PCR from Perkin-Elmer), and both systems amplified the two GC-rich templates (MHCcln1 and OCT-T1) only after the addition of DMSO or betaine. These observations suggest that the two-enzyme system can amplify the GC-rich templates in the presence of DMSO or betaine.

\section{Amplification of Heterogeneous DNA Templates}

We tested the relative efficiency of amplification of each template ( $0.5 \mathrm{ng}$ of plasmid DNA) in a mixture of all four templates as the representation of a heterogeneous mixture. PCR was performed in the presence of various concentrations of DMSO, betaine, or a combination of DMSO and betaine (Fig. 1B, lanes 1-10). Uniform amplification of the four templates was achieved only when amplification was performed in a mixture of DMSO and betaine (Fig. 1B, lanes 9,10). All of the templates were amplified to some extent in the presence of $2.2 \mathrm{M}$ betaine, $5 \% \mathrm{DMSO}+2.2 \mathrm{M}$ betaine, or $10 \% \mathrm{DMSO}+1.1 \mathrm{~m}$ betaine (Fig. 1B). However, some of the four templates were not amplified at lower (5\% or 10\% DMSO, $1.1 \mathrm{M}$ betaine, $5 \%$ DMSO $+1.1 \mathrm{~m}$ betaine) or higher $(10 \%$ $\mathrm{DMSO}+2.2 \mathrm{M}$ betaine) concentration of denaturants (Fig. 1B). We amplified the mixture of the four templates at a fixed concentration of betaine $(1.0 \mathrm{M})$ with various concentrations of DMSO, 
A
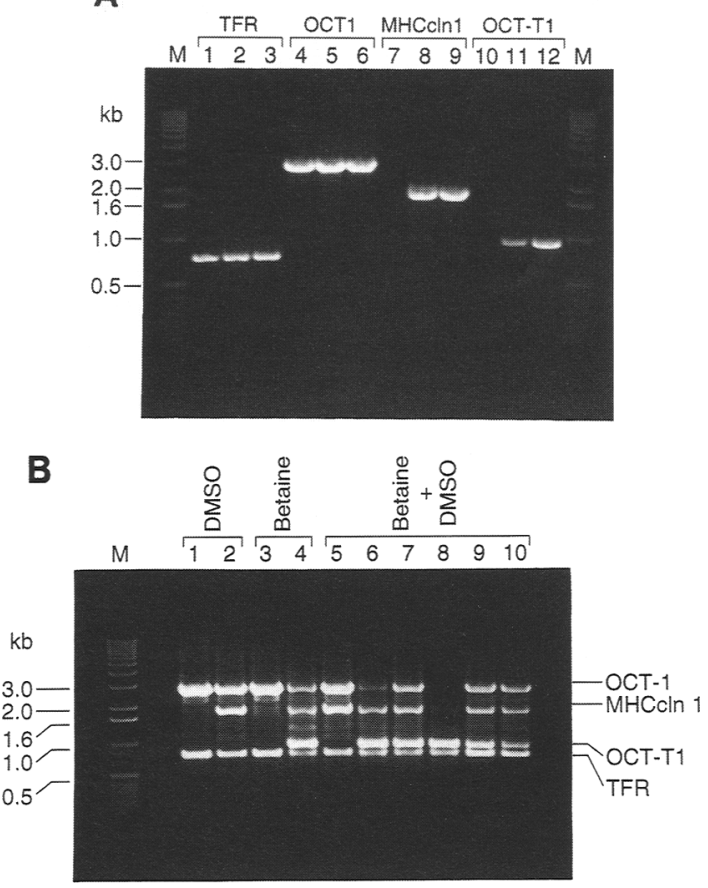

and also at a fixed concentration of DMSO (5\%) and various concentrations of betaine. A combination of $1.0 \mathrm{M}$ betaine with $6 \%-8 \%$ DMSO or $5 \%$ DMSO with 1.2-1.8 $\mathrm{m}$ betaine facilitated approximately uniform amplifications. As a representative result, the uniform amplifications of all four templates are shown in Fig. 1B (lanes 9,10) when the PCR reactions were performed in the presence of $7 \%$ DMSO $+1.0 \mathrm{~m}$ betaine and $5 \%$ DMSO $+1.4 \mathrm{~m}$ betaine. Although all of the templates were amplified to some extent at a higher concentration of DMSO (12\%-15\%) or betaine (1.8-2.5 M) (data not shown), approximately equimolar yield of individual components of the template mixture was obtained only when DMSO and betaine were combined.

\section{Amplification of CGG Repeat from Fragile X Region}

We also applied this protocol for the amplification of the GC-rich CGG repeat region from the fragile $\mathrm{X}$ region (>85\% GC) from genomic DNA template. JY, a lymphoblastoid cell line, genomic DNA (29 CGG repeats), two male genomic DNAs with a premutation (74 and 119 CGG repeats), and two samples of DNA from patients carrying full mutation (>1000 CGG repeats) were used for the amplification of the CGG repeat region from

\section{UNIFORM AMPLIFICAIION OF A DNA MIXIURE}

Figure 1 (A) Amplification of DNA templates with differing GC contents (TFR, 44\% GC; OCT1, 52\% GC; MHCCln1, 62\% GC; OCT-T1, $80 \%$ GC) was performed essentially as described in Methods. One nanogram of each plasmid, $50 \mathrm{ng}$ of each primer, and $0.2 \mu \mathrm{l}$ of KlentaqLA-16 were used for amplification. The amplification was done in the presence and absence of denaturants (10\% DMSO or $2.0 \mathrm{M}$ betaine). The cycling conditions used were as follows: denaturation at $95^{\circ} \mathrm{C}$ for $15 \mathrm{sec}$, annealing at $55^{\circ} \mathrm{C}$ for $1 \mathrm{~min}$, and extension at $68^{\circ} \mathrm{C}$ for $5 \mathrm{~min}$ for 25 cycles. Lane $M$ corresponds to the 1-kb ladder from GIBCO-BRL. (Lane 1) TFR; (lane 2) TFR + 10\% DMSO; (lane 3) TFR + $2.2 \mathrm{M}$ betaine; (lane 4) OCT1; (lane 5) OCT1 + 10\% DMSO; (lane 6) OCT1 + $2.2 \mathrm{M}$ betaine; (lane 7) MHCcln1; (lane 8) MHC$\mathrm{cln} 1+10 \%$ DMSO; (lane 9) MHCcln $1+2.2 \mathrm{M}$ betaine; (lane 10) OCT-T1; (lane 11) OCT-T1 + 10\% DMSO; (lane 12) OCT-T1 + $2.2 \mathrm{M}$ betaine. (B) Amplification of a mixture of DNA templates in the presence of DMSO and betaine. Amounts of $0.5 \mathrm{ng}$ of all four templates differing in size $(0.72-2.7 \mathrm{~kb})$ and GC contents ( $44 \%-80 \%$ GC) were mixed and used for amplification in the presence of DMSO (5\%-10\%), betaine (1.1-2.2 M betaine), or a combination of DMSO and betaine. The PCR reaction conditions were as described in Methods. The cycling conditions used were as follows: denaturation at $95^{\circ} \mathrm{C}$ for $15 \mathrm{sec}$, annealing at $55^{\circ} \mathrm{C}$ for $1 \mathrm{~min}$, and extension at $68^{\circ} \mathrm{C}$ for $5 \mathrm{~min}$ for 25 cycles. Lane $\mathrm{M}$ corresponds to the 1-kb ladder from GIBCO-BRL. Each lane contains the four templates plus DMSO/ betaine as described. (Lane 1) +5\% DMSO; (lane 2) $+10 \%$ DMSO; (lane 3) $+1.1 \mathrm{M}$ betaine; (lane 4) + 2.2 M betaine; (lane 5) + (5\% DMSO + $1.1 \mathrm{M}$ betaine); (lane 6$)+(5 \%$ DMSO $+2.2 \mathrm{M}$ betaine); $($ lane 7$)+(10 \%$ DMSO + 1.1 M betaine $)$ (lane 8$)+(10 \%$ DMSO $+2.2 \mathrm{M}$ betaine); (lane 9) $+(7 \%$ DMSO + 1.0 M betaine); (lane 10$)+(5 \%$ DMSO + $1.4 \mathrm{M}$ betaine).

the fragile $X$ region. The size of the CGG repeat of these DNA samples was determined by Southern blotting and probing with pE5.1 (Pieretti et al. 1991). We initially used JY genomic DNA to test the amplification of the CGG repeat region under various conditions (10\%-20\% DMSO, up to $2.5 \mathrm{M}$ betaine, or a combination of DMSO and betaine). The expected 300-bp PCR product was observed in the presence of $10 \%$ DMSO, $2.2 \mathrm{~m}$ betaine, and $7 \% \mathrm{DMSO}+1.1 \mathrm{~m}$ betaine (Fig. 2A, lanes 3, 6, and 7 , respectively). A similar extent of amplification was also observed when PCR was performed in the presence of $5 \%$ DMSO and $2.0 \mathrm{~m}$ betaine (Fig $2 \mathrm{~B}$, lane 1$)$. The expected size PCR products were observed for the DNA containing 74 CGG repeats (440 bp) and 119 CGG repeats (575 bp) (Fig. 2B, 
BASKARAN EI AL.

A

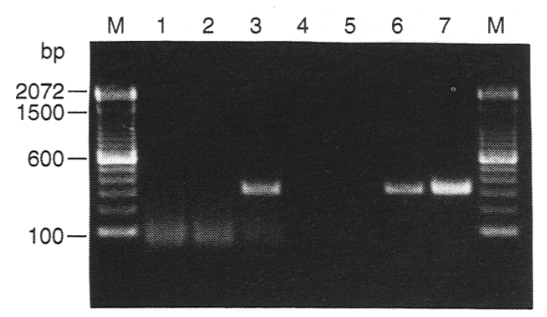

B

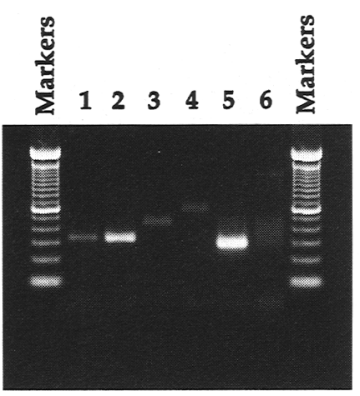

Figure 2 (A) Amplification of the fragile X CGC repeat region from JY genomic DNA was done (as described in Methods) using $10 \mathrm{ng}$ of JY genomic DNA and $50 \mathrm{ng}$ of each of the primers. The cycling conditions used were as follows: denaturation at $95^{\circ} \mathrm{C}$ for $15 \mathrm{sec}$, annealing at $65^{\circ} \mathrm{C}$ for $1 \mathrm{~min}$, and extension at $68^{\circ} \mathrm{C}$ for $5 \mathrm{~min}$ for 40 cycles. The denaturants (DMSO and betaine) were added in the reaction mix, and PCR was begun, as described in Methods. (Lane M) 100-bp ladder from GIBCO-BRL. (Lane 1) No DNA control; (lane 2) no denaturants added; (lane 3) 10\% DMSO; (lane 4) 20\% DMSO; (lane 5) $1.1 \mathrm{M}$ betaine; (lane 6) $2.2 \mathrm{M}$ betaine; (lane 7) $7 \%$ DMSO + $1.1 \mathrm{M}$ betaine. (B) Amplification of the fragile $X$ CGG repeat region from premutation and full-mutation DNA samples. The reaction conditions for amplification were essentially as described in Methods using $100 \mathrm{ng}$ of genomic DNA in the presence of $5 \%$ DMSO and $2.0 \mathrm{M}$ betaine. The cycling conditions used were as follows: denaturation at $95^{\circ} \mathrm{C}$ for $15 \mathrm{sec}$, annealing at $65^{\circ} \mathrm{C}$ for 1 min, and extension at $68^{\circ} \mathrm{C}$ for $5 \mathrm{~min}$ for 40 cycles. (Markers) The 100-bp ladder from GIBCO-BRL. (Lane 1) IY DNA (10 ng); (lane 2) IY DNA (100 ng); (lane 3) 74 CGG repeat genomic DNA from a male (100 ng); (lane 4) 119 CGG repeat genomic DNA from a male (100 ng); (lane 5) heterozygous full mutation ( $>1000$ CGG repeats) in a female genomic DNA (100 ng); (lane 6) full mutation ( $>1000$ CGG repeats) in a male genomic DNA (100 ng). Ten microliters of the PCR product was loaded onto each well except lanes 3,4 , and 6 , which received $20 \mu$ l.

lanes 3,4). A smear of low molecular weight products $(300 \mathrm{bp})$ and a faint band at $1.3 \mathrm{~kb}$, probably attributable to nonspecific amplification or PCRmediated truncation, was observed for the DNA from a male patient carrying a full mutation (Fig. $2 \mathrm{~B}$, lane 6 ), and only a normal size repeat band $(300 \mathrm{bp}$ ) was observed for a DNA sample from a female patient carrying a full mutation as well as a normal gene (Fig. 2B, lane 5). Thus, the normal size repeat (average, 29 CGG repeats) and premutation repeat expansion can be amplified by this method, whereas the full mutation causing the disease ( $>200$ repeats) is recalcitrant.

Several PCR methods have been designed to amplify the CGG triplet repeat region of the fragile $X$ site involving different thermostable DNA polymerases and DMSO and/or different ratios of 7cdGTP and dGTP in the PCR reaction (Fu et al. 1991; Chong et al. 1994; Cao et al. 1994; Levinson et al. 1994; Wang et al. 1995). The substitution of 7cdGTP in the PCR reaction results in less ethidium bromide staining, and detection of the PCR products by UV is often difficult. The 7cdGTP-substituted PCR products are often detected indirectly by using a radioactive probe, or the ratio of dGTP/7cdGTP is modified so that the product can be detected after ethidium staining (Fu et al. 1991; Chong et al. 1994; Cao et al. 1994; Levinson et al. 1994; Wang et al. 1995). As the present method does not involve the use of 7cdGTP, the resulting PCR products are readily detected by ethidium staining. However, none of the methods can amplify the CGG repeats from the fragile $X$ region from patients with the full mutation (>200 CGG repeats).

Although our method did not amplify extensively long CGG repeats, it combines the benefits of long PCR and amplification of templates with high GC content. This protocol will be applicable in many experiments in molecular biology such as construction of cDNA libraries from small numbers of cells, construction of jumping and linking libraries, normalization of cDNA libraries, representational differential analysis of genomic DNA, cDNA selection, amplification of cDNA fragments corresponding to the $5^{\prime}$ ends of mRNA, amplification of HTF islands, and use as a diagnostic tool for detection of various triplet repeat expansion diseases. In conclusion, we have described here a method for uniform amplification of a heterogeneous population of DNA molecules and applied this method to amplify the CGG repeat from the fragile $\mathrm{X}$ region.

\section{METHODS}

Amplitaq DNA polymerase $(2.5 \mathrm{U} / \mu \mathrm{l})$ was purchased from Perkin-Elmer Cetus. Klentaq1 DNA polymerase $(25 \mathrm{U} / \mu \mathrm{l})$ 


\section{UNIFORM AMPLIFICATION OF A DNA MIXIURE}

and $P f u$ DNA polymerase $(2.5 \mathrm{U} / \mu \mathrm{l})$ were purchased from $\mathrm{Ab}$ peptides (St. Louis, MO) and Stratagene (La Jolla, CA), respectively. Betaine, TMAC, and TMAA were purchased from Aldrich Chemical Co. These compounds were dissolved in water, and the $\mathrm{pH}$ was adjusted to 9 using Tris base. Betaine dissolved in water without neutralization was also as effective as neutralized betaine in the amplification of DNA templates when tested using individual templates.

The four test templates used were cloned in the Bluescript or pUC18 plasmid: (1) a 0.72-kb 5' end of TFR ( $44 \%$ GC; nucleotides 352-866; GenBank accession no. X01060); (2) a 2.7-kb cDNA encoding OCT1 (52\% GC; X13403) (Sturm et al. 1988); (3) a 1.6-kb NotI-linking clone in pUC18, MHCcln1 (64\% GC) (Shukla et al. 1991); and (4) a $0.8-\mathrm{kb} 5^{\prime}$ end fragment of OCT-T1 cDNA (80\% GC; nucleotides 318-850 of L20433) (Bhargava et al. 1993). The sizes shown above for each template (except MHC$\operatorname{cln} 1$, which includes $100 \mathrm{bp}$ of the multiple cloning site) included $250 \mathrm{bp}$ of the multiple cloning sites of Bluescript vector in the PCR product. The CGG repeat of the fragile $\mathrm{X}$ site was amplified using primer $C\left(5^{\prime}\right.$-GCTCAGCTCCGTTTCGGTTTCACTTCCGGT-3') and F (5' AGCCCCGCACTTCCACCACCAGCTCCTCCA-3') described earlier (Fu et al. 1991).

Standard PCR with AmpliTaq DNA polymerase was conducted in Tris buffer $\left[10 \mathrm{~mm}\right.$ Tris- $\mathrm{HCl}\left(\mathrm{pH} 8.3\right.$ at $\left.25^{\circ} \mathrm{C}\right)$, $50 \mathrm{~mm} \mathrm{KCl}, 1.5 \mathrm{~mm}$ magnesium chloride] containing 200 $\mu \mathrm{M}$ of each dNTP, $50 \mathrm{ng}$ of each primer (M13 forward and reverse, 24-mer), and 1 unit of the enzyme (Saiki et al. 1988). The two-enzyme PCR approach referred to as long and accurate PCR (LA-PCR) was followed essentially as described using Klentaq1 and Pfu DNA polymerase (Barnes 1994). The reaction mixture $(50 \mu \mathrm{l})$ consisted of $20 \mathrm{mM}$ Tris- $\mathrm{HCl}\left(\mathrm{pH} 9.0\right.$ at $25^{\circ} \mathrm{C}$ ) buffer, bovine serum albumin $(150 \mu \mathrm{g} / \mathrm{ml}), 16 \mathrm{~mm}$ ammonium sulfate, $2.5 \mathrm{~mm}$ magnesium chloride, $200 \mu \mathrm{M}$ of each dNTP, $50 \mathrm{ng}$ of each primer (M13 forward and reverse), and 0.5-1 ng of plasmid templates. Klentaq1 (15 parts) and Pfu DNA polymerase (1 part) were mixed by volume and referred to as KlentaqLA16 (Barnes 1994). For each reaction, 0.2-0.4 $\mu$ l of KlentaqLA-16 was used. The PCR was performed in an Omnigene (Hybaid) PCR machine using thin-walled tubes $(0.5$ $\mathrm{ml}$ ) from Costar. The following cycling conditions were selected for 25 cycles: denaturation at $94^{\circ} \mathrm{C}$ for $15 \mathrm{sec}$, annealing at $50^{\circ} \mathrm{C}-55^{\circ} \mathrm{C}$ for $1 \mathrm{~min}$, and extension at $68^{\circ} \mathrm{C}$ for $5 \mathrm{~min}$. All of the reaction components were mixed without dNTPs and overlaid with mineral oil. The tubes were heated at $95^{\circ} \mathrm{C}$ for $15 \mathrm{sec}$, and the PCR was started by the addition of dNTPs at $80^{\circ} \mathrm{C}$. At the end of the PCR, $10 \mu \mathrm{l}$ of the product was loaded onto a $1 \%$ agarose gel. The DNA was stained with ethidium bromide and photographed with a Stratagene Eagle Eye equipped with a transilluminator. Various combinations of reagents such as betaine, DMSO, glycerol, formamide, TMAC, or TMAA were added to the PCR reaction mixture, and amplifications were performed with either AmpliTaq or the LA system.

Amplification of the CGG repeat region of the fragile $\mathrm{X}$ site was performed in the reaction mixture as described above with the following modifications. To the above PCR reaction $\mathrm{mix}, 7 \% \mathrm{DMSO}+1.1 \mathrm{M}$ betaine or $5 \%$ $\mathrm{DMSO}+2.0 \mathrm{M}$ betaine was added. Fifty nanograms of primer $\mathrm{C}$ and $\mathrm{F}$ were added for each tube. Genomic DNA (10 or $100 \mathrm{ng}$ ) from each of the samples, prepared from peripheral blood lymphocytes, was used for each reaction.
The amplification was performed using the following cycling conditions: denaturation at $94^{\circ} \mathrm{C}$ for $15 \mathrm{sec}$, annealing at $65^{\circ} \mathrm{C}$ for $1 \mathrm{~min}$, and extension at $68^{\circ} \mathrm{C}$ for $5 \mathrm{~min}$ for 40 cycles. Alternatively, the annealing and extension was done at $68^{\circ} \mathrm{C}$ for $5 \mathrm{~min}$. Ten microliters of the PCR product was loaded onto a $2 \%$ agarose gel, and the bands were visualized by ethidium bromide staining.

\section{ACKNOWLEDGMENTS}

We are thankful to Drs. H. Shukla (Smith Kline Beecham), P. Kulkarni (Yale University), and A. Capossela for their generous gifts of MHCcln1, OCT1 and the $5^{\prime}$ end of TFR, respectively. We are also grateful to Dr. S.R. Patanjali for helpful suggestions in the preparation of this manuscript.

The publication costs of this article were defrayed in part by payment of page charges. This article must therefore be hereby marked "advertisement" in accordance with 18 USC section 1734 solely to indicate this fact.

\section{REFERENCES}

Barnes, W.M. 1992. The fidelity of Taq polymerase catalyzing PCR is improved by an N-terminal deletion. Gene 112: 29-35.

1994. PCR amplification of up to 35-kb DNA with high fidelity and high yield from $\lambda$ bacteriophage templates. Proc. Natl. Acad. Sci. 91: 2216-2220.

Bhargava, A.K., Z. Li, and S.M. Weissman. 1993. Differential expression of four members of the POU family of proteins in activated and phorbol 12-myristate 13-acetate-treated Jurkat T cells. Proc. Natl. Acad. Sci. 90: $10260-10264$.

Bookstein, R., C. Lai, H. To, and W. Lee. 1990. PCR-based detection of a polymorphic BamHI in intron 1 of the human retinoblastoma gene. Nucleic Acids Res. 18: 1666 .

Cao, J., J. Tarleton, D. Barberio, and L.S. Davidow. 1994. A simple fragile X PCR assay with 7-deazaguaninesubstituted DNA visualized by ethidium bromide. $\mathrm{Mol}$. Cell. Probes 8: 177-180.

Cheng, S., C. Fockler, W.M. Barnes, and R. Higuchi. 1994. Effective amplification of long templates from cloned inserts and human genomic DNA. Proc. Natl. Acad. Sci. 91: 5695-5699.

Chevet, E., G. Lemaitre, and D. Katinka. 1995. Low concentrations of tetramethylammonium chloride increase yield and specificity of PCR. Nucleic Acids Res. 23: $3343-3344$.

Chong, S.S., E.E. Eichler, D.L. Nelson, and M.R. Hughes. 1994. Robust amplification and ethidium-visible detection of the fragile $\mathrm{X}$ syndrome CGG repeat using Pfu polymerase. Am. J. Med. Genet. 51: 522-526.

Csonka, L.N. 1989. Physiological and genetic responses of bacteria to osmotic stress. Microbiol. Rev. 53: 121-147. 


\section{BASKARAN EI AL.}

Foord, O.S. and E.A. Rose. 1994. Long-distance PCR. PCR Methods Applic. 3: $\$ 149-\$ 161$.

Fu, Y.-H., D.P.A. Kuhl, A. Pizzuti, M. Pieretti, J.S. Sutcliffe, S. Richards, A.J.M.H. Verkerk, J.J.A. Holden, R.G. Fenwick Jr., S.T. Warren, B.A. Oostra, D.L. Nielson, and C.T. Caskey. 1991. Variation of the CGG repeat at the fragile $\mathrm{X}$ site results in genetic instability: Resolution of the Sherman paradox. Cell 67: 1047-1058.

Hung, T., K. Mak, and K. Fong. 1990. A specificity enhancer for polymerase chain reaction. Nucleic Acids Res. 18: 4953.

Lawyer, F.C., S. Stoffel, R.K. Saiki, S. Chang, P.A. Landre, R. Abramson, and D. Gelfand. 1993. High level expression, purification, and enzymatic characterization of full-length Thermus aquaticus DNA polymerase and a truncated form deficient in $5^{\prime}$ to $3^{\prime}$ exonuclease activity. PCR Methods Applic. 2: 275-287.

Levinson, G., A. Maddalena, F.T. Palmer, G.L. Harton, D.P. Bick, P.N. Howard-Peebles, S.H. Black, and J.D. Schlman. 1994. Improved sizing of fragile X CGG repeats by nested polymerase chain reaction. Am. J. Med. Genet. 51: 527-534.

Lundberg, K.S., D.D. Shoemaker, M.W.W. Adam, J.M. Short, J.A. Sorge, and E.J. Mathur. 1991. High-fidelity amplification using a thermostable DNA polymerase isolated from Pyrococcus furiosus. Gene 108: 1-6.

Mattila, P., J. Korpela, T. Tenkanen, and K. Pitkanen. 1991. Fidelity of DNA synthesis by the Thermococus litoralis DNA polymerase-An extremely heat stable enzyme with proofreading activity. Nucleic Acids Res. 19: $4967-4973$.

McConlogue, L., M.A. Brow, and M.A. Innis. 1988. Structure-independent DNA amplification of PCR using 7-deaza-2'-deoxyguanosine. Nucleic Acids Res. 16: 9869.

Melchior, W.B. Jr. and P.H. von Hippel. 1973. Alteration of the relative stability of dA.dT and dG.dC base pairs in DNA. Proc. Natl. Acad. Sci. 70: 298-302.

Pieretti, M., F. Zhang, Y.-H. Fu, S.T. Warren, B.A. Oostra, C.T. Caskey, and D.L. Nelson. 1991. Absence of expression of FMR-1 gene in fragile X syndrome. Cell 66: $817-822$.

Pomp, D. and J.F. Medrano. 1991. Organic solvents as facilitators of polymerase chain reaction. BioTechniques 10: $58-59$.

Rees, W.A., T.D. Yager, J. Korte, and P.H. von Hippel. 1993. Betaine can eliminate the base pair composition dependence of DNA melting. Biochemistry 32: 137-144.

Saiki, R.K., D.H. Gelfand, S. Stoffel, S.J. Scharf, R. Higuchi, G.T. Horn, K.B. Mullis, and H.A. Erlich. 1988. Primer-directed enzymatic amplification of DNA with a thermostable DNA polymerase. Science 239: 487-491.
Santoro, M.M., Y. Liu, S.M.A. Khan, L.-X. Hou, and D.W. Bolen. 1992. Increased thermal stability of proteins in the presence of naturally occurring osmolytes. Biochemistry 31: 5278-5283.

Sarkar, G., S. Kapelner, and S.S. Sommer. 1990. Formamide can dramatically improve the specificity of PCR. Nucleic Acids Res. 18: 7465.

Shukla, H., Y. Kobayashi, H. Arsentorf, Y. Yasukochi, and S.M. Weissman. 1991. Purification of BsuE methyltransferase and its application in genome mapping. Nucleic Acids Res. 19: 4233-4239.

Sturm, R.A., G. Das, and W. Herr. 1988. The ubiquitous octamer-binding protein Oct-1 contains a POU domain with a homeo box subdomain. Genes \& Dev. 2: 1582-1599.

Wang, Q., E. Green, M. Bobrow, and C.G. Mathew. 1995. A rapid, non-radioactive screening test for fragile $X$ mutations at the FRAXA and FRAXE loci. J. Med. Genet. 32: 170-173.

Received November 28, 1995; accepted in revised form May 20, 1996. 


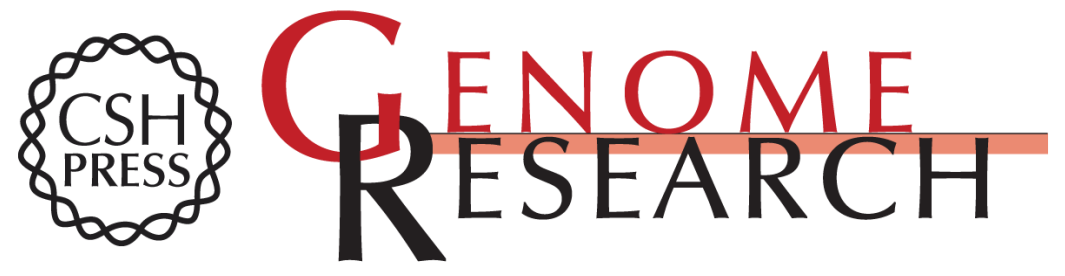

\section{Uniform amplification of a mixture of deoxyribonucleic acids with varying $\mathbf{G C}$ content.}

N Baskaran, R P Kandpal, A K Bhargava, et al.

Genome Res. 1996 6: 633-638

Access the most recent version at doi:10.1101/gr.6.7.633

References This article cites 27 articles, 8 of which can be accessed free at:

http://genome.cshlp.org/content/6/7/633.full.html\#ref-list-1

\section{License}

Email Alerting Receive free email alerts when new articles cite this article - sign up in the box at the Service top right corner of the article or click here.

\section{Affordable, Accurate Sequencing.}

To subscribe to Genome Research go to:

https://genome.cshlp.org/subscriptions 